\title{
Determination of Moisture Content of Insulating Oils by $\mathrm{CoCl}_{2}$
}

\author{
Kozlov V.K ${ }^{1}$., Turanova O.A ${ }^{2}$, Kurakina O.E. ${ }^{1}$, Turanov A.N. ${ }^{2}$ \\ ${ }^{1}$ Kazan State Power Engineering University, \\ ${ }^{2}$ Zavoisky Physical-Technical Institute, FRC Kazan Scientific Center of RAS, \\ Kazan, Russian Federation
}

\begin{abstract}
Moisture content is one of the parameters of transformer oil that determine its quality. This parameter is one of the most critical, which is closely monitored. During the operation of transformer oil in the power equipment of electric power systems, about 10 grams of water per ton of oil is allowed, i.e. the permissible proportion of water is $10 \mathrm{ppm}(\mathrm{ppm})$. The aim of the work is to develop a new method for determining the permissible proportion of water in transformer oil in small quantities. This goal is achieved by performing spectral studies of transformer oil samples in the UV and visible range with the addition of cobalt (II) chloride $(\mathrm{CoCl} 2)$ powder. Cobalt (II) chloride has the ability to change its color depending on the amount of water of crystallization. The most significant result of the article is the conclusion, obtained on the basis of the recorded spectra, about the relationship between the optical density of the spectrum in the range of $360-490 \mathrm{~nm}$ and the moisture content of transformer oil when adding cobalt chloride powder. The significance of the results obtained is that the authors have proposed a new optical method for determining small values of the proportion of water in transformer oils, based on the dependence of the optical properties of cobalt (II) chloride on moisture content.This method has a very high sensitivity, low cost for determining the proportion of water and is very promising for solving problems of power energy.
\end{abstract}

Keywords: insulating oil, water, crystalline hydrate, cobalt (II) chloride, absorption spectra.

DOI: https://doi.org/10.52254/1857-0070.2021.1-49.07

UDC: 621.315.615.22

\section{Determinarea conținutului de umiditate al uleiurilor izolante folosind $\mathrm{CoCl}_{2}$ Kozlov V.K. ${ }^{1}$, Turanova O.A. ${ }^{2}$, Kurakina O.E. ${ }^{1}$, Turanov A.N. ${ }^{2}$ \\ ${ }^{1}$ FGBOU VPO Universitatea de Stat de energetică din Kazani, ${ }^{2}$ Instituttul Fizico-tehnic E.K. Zavoiski din Kazani FIȚ «KazCȘ AȘR», Kazani, Federația Rusă}

Rezumat. Utilaj transformator este o parte importantă a sistemului energetic, iar funcționarea sa neîntreruptă şi fiabilă este cheia alimentării cu energie electrică de înaltă calitate a consumatorilor. Majoritatea transformatoarelor acționate folosesc uleiul de transformare ca dielectric și ca mediu de răcire. Conținutul de umiditate este unul dintre parametrii uleiului de transformator care determină calitatea acestuia. La concentrații mai mari de apă, există riscul defectării transformatoarelor de putere, ceea ce complică funcționarea lor ulterioară și, în consecință, performanța întregului sistem de alimentare. Scopul lucrării este de a dezvolta o nouă metodă pentru determinarea fracției admisibile de apă în uleiul de transformator în cantități mici. Acest obiectiv este realizat prin efectuarea de studii spectrale ale probelor de ulei de transformator în domeniul UV vizibil, cu adăugarea de pulbere de clorură de cobalt (II) $(\mathrm{CoCl} 2)$. Clorura de cobalt (II) are capacitatea de a-şi schimba culoarea în funcție de cantitatea de apă de cristalizare. Cel mai important rezultat al articolului este concluzia, obținută pe baza spectrelor înregistrate, privind relația dintre densitatea optică a spectrului în intervalul 360-490 nm și conținutul de umiditate al uleiului de transformator la adăugarea pulberii de clorură de cobalt. Semnificația rezultatelor obținute constă în faptul, că metodă optică pentru determinarea unor valori mici ale proporției apei din uleiurile de transformare, bazată pe dependența proprietăților optice ale clorurii de cobalt (II) de conținutul de umiditate are o sensibilitate foarte mare, un cost redus pentru determinarea proporției de apă și este foarte promiţătoare pentru rezolvarea problemelor de energie electrică.

Cuvinte-cheie: uleiul izolant, apă, hidrat cristalin, clorură de cobalt (II), spectre de absorbție.

\section{Определение влагосодержания изоляционных масел с помощью $\mathrm{CoCl}_{2}$ Козлов В.К. ${ }^{1}$, Туранова О.А. ${ }^{2}$, Куракина О.Е. ${ }^{1}$, Туранов А.Н. ${ }^{2}$ \\ ${ }^{1}$ ФГБОУ ВПО Казанский государственный энергетический университет, ${ }^{2}$ Казанский физико-технический институт им. Е.К. Завойского ФИЦ «КазНЦ РАН», Казань, Российская федерация}

Аннотация. Трансформаторное оборудование является важной частью энергосистемы, а его бесперебойная и надежная работа является залогом качественного электроснабжения потребителей. Основная часть эксплуатируемых трансформаторов в качестве диэлектрика и охлаждающей среды использует трансформаторное масло. Влагосодержание - это один из параметров трансформаторного 
масла, определяющих его качество. Данный параметр является одним из наиболее критических, за которым ведется тщательный контроль. При эксплуатации трансформаторного масла в силовом оборудовании электроэнергетических систем допускается присутствие влаги порядка 10 грамм воды на тонну масла, т.е. допустимая доля воды - 10 миллионных долей (м.д.). При повышенных концентрациях воды возникает риск выхода из строя силовых трансформаторов, что осложняет их дальнейшую эксплуатацию и, следовательно, работоспособность всей энергосистемы. Целью работы является разработка нового метода определения допустимой доли воды в трансформаторном масле в малых количествах. Поставленная цель достигается за счет проведения спектральных исследований образцов трансформаторного масла в УФ и видимом диапазоне с добавлением порошка хлорида кобальта(II) $\left(\mathrm{CoCl}_{2}\right)$. Хлорид кобальта (II) обладает способностью изменять свой цвет в зависимости от количества кристаллизационной воды. Наиболее существенным результатом статьи является вывод, полученный на основании записанных спектров, о взаимосвязи величины оптической плотности спектра в диапазоне 360-490 нм и влагосодержанием трансформаторного масла при добавлении порошка хлорида кобальта.

Значимость полученных результатов состоит в том, что оптический метод определения малых значений доли воды в трансформаторных маслах, основанный на зависимости оптических свойств хлорида кобальта (II) от влагосодержания, обладает очень высокой чувствительностью, малыми затратами для определения доли воды и весьма перспективен для решения задач силовой энергетики.

Ключевые слова: изоляционное масло, вода, кристаллогидрат, хлорид кобальта (II), спектры поглощения.

\section{INTRODUCTION}

Transformer oil is a highly purifed product of oil refining, an electrical insulating material, an arc-extinguishing and heat-removing medium, as well as an environment that protects the solid insulation of the transformer (cardboard) from moisture and air penetration. It possesses excellent antioxidant properties, which makes it possible to maintain long-term operation of electric power equipment. In the electrical industry it is used for filling power and measuring transformers, reactor equipment, oil switches.

During the operation of transformers, the oils filled in them undergo profound changes, which are usually characterized by the concept of "deterioration", including changes in its chemical and electrophysical properties.

Deterioration of transformer oil causes oxidative processes. The oxidation process is influenced by such a characteristic as the moisture content of the oil [1].

The main source of water in the transformer is atmospheric moisture. It enters the transformer together with air through imperfect humidification protection systems. Along with this, the source of moisture is also air, which penetrates through the seals (if they are defective) under the influence of a pressure gradient. In addition to the ingress of moisture into the oil from the surrounding atmosphere, there is a water source in the transformer itself the water generated in the transformer is released from the solid insulation as a result of the deterioration process. In a fully loaded transformer under rated load, cellulose insulation loses its insulating properties within 20-30 years and releases about $0.5-0.75 \%$ of water (based on the insulation mass) during this time [2].

During the operation of transformer oil in the power equipment of electric power systems, moisture of about 10 grams of water per ton of oil is allowed, i.e. the permissible proportion of water is $10 \mathrm{ppm}$ (ppm). This value is very small and it is difficult to determine it using existing methods. In addition to the existing difficulties, very often the accuracy of the measurement results is questioned.

Currently, the most widely used volumetric and coulometric versions of Karl Fischer (KF) titration are used to determine the moisture content of oils [3,4]. The accuracy of determining the permissible water content (W) by these methods exceeds $1 \mathrm{ppm}$. The reaction can be divided into three key stages: water reacts with sulfur dioxide, as a result of which $I_{2}$ is reduced to I-, the released sulfur trioxide forms a complex with pyridine, which in the presence of alcohol is converted into a stable pyridine complex. Thus, one equivalent of iodine is consumed to titrate each water equivalent.

In volumetric KF titration, the burette is filled with a reagent, and a solvent is added to the titer cell, which is previously titrated. Thus, residual moisture is removed from the added solvent, from the atmosphere, from the walls of the cell and the electrode. Then, an oil sample of a certain volume is fed into the dried working medium, which depends on the desired accuracy of the result, the amount of water contained in 
the sample, the volume of the burette and the titer of the reagent. Titration starts immediately after adding the sample.

Coulometric water titration is based on the reaction of anodic oxidation of the iodide anion with the formation of iodine, which is necessary for the KF reaction. A certain amount of HM is introduced into the cell with an iodine-containing reagent, and a polarization potential is applied to the electrodes in the cell. When water interacts with iodine, free ions appear, which cause an increase in conductivity. To maintain a given polarization current, a decrease in the voltage applied to the electrodes is required. The moisture content is determined according to Faraday's law, according to which the amount of water is proportional to the amount of charge. The moisture determination accuracy exceeds 1 ppm.

However, the results of a large number of studies on the accuracy and reproducibility of $\mathrm{W}$ by titration of TM according to KF [5-10] showed that this method is practically insensitive to dispersed water, which cannot interact with the KF reagent. In addition, for the correct determination of $\mathrm{W}$, it is necessary to take into account: - acids and bases formed during the operation of TM (acidity of the working medium should be within 5-7 $\mathrm{pH}$ ); - slowly proceeding side reactions (consumption of $I_{2}$ in a chemical reaction with organic components of oil with double bonds, which leads either to an increased coulometric reduction of iodine, or to an increased addition of the CF reagent); - limited solubility of long-chain and condensed hydrocarbons in methanol; - the presence of compounds that slowly release water, such as crystalline hydrates, reduces the accuracy of determining the end point of titration; - the presence in the HM operating under real conditions of compounds, for example, aldehydes and ketones, reacting with methanol with the release of water.

It should be noted that in order to solve the abovementioned, testing and the introduction of new reagents for titration by KF are constantly being carried out, for example, very good results were obtained by replacing toxic pyridine with imidazole. In addition, attempts are being made to improve the technique. Several indirect methods that involve sample heating such as tube evaporation, azeotropic distillation, and headspace gas chromatography have been developed to eliminate the need to inject the sample directly into the titration cell.
However, it turned out that some of the water contained in the heterogeneous solution phase can be so strongly bound to the oil that it remains inaccessible for titration even under such conditions.

For a long time, the calcium hydride method has been used [3,4], the essence of which is the interaction of calcium hydride with water dissolved in oil and the calculation of its mass fraction by the volume of hydrogen released.

The method is suitable only for oils that do not contain emulsion water [11].The methods most frequently used in practice can be found in [12].

In connection with the imperfection of existing methods, the search for new methods for determining the moisture content in transformer oil continues. For example, determination of moisture content in transformer oil using platinum-coated D-shaped optical fiber [11]. In the last decade, capacitive sensors are used to assess the moisture content of power transformers [14] increasingly, they are most fully considered in [13, 15-19].

The next method for determining the moisture content in transformer oil, which is widespread at the moment, is gas chromatography [20]. The essence of the gas chromatography method lies in the fact that the analytes in the vapor state with the carrier gas flow pass through a column with a stationary liquid phase deposited on a solid carrier. As they move along the column, the substances are constantly redistributed between phases due to the repeated repetition of sorptiondesorption processes and are separated due to the difference in the distribution coefficients. Then, the separated substances are eluted from the chromatographic column with a carrier gas flow, recorded by a detector, and recorded in the chromatogram as peaks.

The method has an accuracy of the order of 1 ppm. However, the need for the correct selection of the chromatogram recording rate, the column load with the analyte, as well as the solid carrier used for the preparation of the sorbent complicates the analysis and, accordingly, reduces its accuracy [21].

In the method of mass spectrometry of a substance by determining the ratio of mass to charge (quality) and the number of charged particles formed during a particular process of exposure to a substance. A significant difference between mass spectrometry and other analytical physicochemical methods for determining $\mathrm{W}$ is that optical, X-ray, and some other methods 
detect the emission or absorption of energy by molecules or atoms, while mass spectrometry directly detects the particles of a substance.

This method has sufficient accuracy (1 ppm) [22], but the complexity and significant cost of equipment for mass spectroscopy significantly limit the widespread use of this method for the analysis of insulating oils in power electric power industry.

In the method of photo-acoustic spectroscopy, thermal radiation from a heat-stabilized wire is focused by a parabolic mirror, passes through disks with slots and filters with different wavelength ranges, and enters a chamber with gas. The radiation causes a pulsating expansion of the gas, which is detected by a sensitive microphone. Since each gas has a characteristic absorption spectrum, the level of which is proportional to the gas concentration, the choice of the range of optical filters makes it possible to determine the mass ratio of substances in the initial system (transformer oil with dissolved gases and water). Comparative analysis of $\mathrm{W}$ of transformer oi determined by this method with the results of chromatography, etc. [23] in $10 \%$ of the samples showed values that were 2-3 times overestimated.

The combination of thermal analysis and coulometry made it possible to develop an analyzer with a sensitivity of several ppm. [24]. After weighing on a microbalance, the of transformer oil sample is gradually heated in a built-in oven (up to $400{ }^{\circ} \mathrm{C}$ ). Water and other components extracted from the sample are transported by a carrier gas $\left(\mathrm{N}_{2}\right.$ or dry air) to an electrochemical sensor, in which a mixture of gases passes over a layer of phosphoric anhydride. Electrolytic dissociation occurs between the molecules of the absorbed water and the phosphoric anhydride layer. The measured electrical current is in direct proportion to the mass of water evaporated from this sample. The method should be thoroughly tested for suitability for determining small values of $\mathrm{W}$ of transformer oil.

All of the listed methods for determining W have both advantages and disadvantages. Now they are at the stage of thorough testing of their suitability for determining small values of $\mathrm{W}$ of transformer oils for power industry purposes.

Recently it was shown that due to the high resolution and sensitivity of $1 \mathrm{H}$ nuclear magnetic resonance spectroscopy, NMR is a direct, visual and highly accurate method of determining $\mathrm{W}$ of transformer oils. Nuclear magnetic resonance
(NMR) spectroscopy is a type of spectroscopy that uses radio-frequency-induced transitions between the energy levels of atomic nuclei [25].The resonance frequency, width and shape of the absorption line in high-resolution proton nuclear magnetic resonance ( ${ }^{1} \mathrm{H}$ NMR) spectra depend not only on the molecular-structural group, which includes the protons, but also on the group's immediate environment. As a result, due to the high sensitivity, it is possible to detect a small amount of water in a liquid sample (less than $1 \mathrm{ppm}$ ), as well as to distinguish water in the states of a true solution and in the composition of dispersed formations (micelles) [26]. However, the high cost and complexity of NMR equipment, as well as high qualification requirements for personnel extremely reduce the possibility of wide use of NMR in laboratory analyses at energy companies.

Power transformers equipping by a system of fiber-optic cables with sensors at the ends opens a new channel of equipment state monitoring [14].

Reviews on how to improve the operation of optical humidity sensors in both gaseous and liquid media are being regularly published in the scientific literature [for example, 27].

Analyzing the currently used methods for determining the moisture content, it can be noted that there is no universal, accurate and low-cost method for an objective analysis of the water content in its various states.

The authors, in search of a solution to the urgent problem of power engineering - determination of $\mathrm{W}$ in transformer oil in small quantities and in various states drew attention to cobalt (II) chloride $\left(\mathrm{CoCl}_{2}\right)$. It is one of the most commonly used optical water sensors $[26,28,29]$. The presented studies are based on the task of creating a method for determining the moisture content of transformer oil in the UV and visible spectral regions using a colorimetric method, the use of which will improve the quality of diagnostics of the transformer oil under study. Cobalt (II) chloride is hygroscopic, and its crystalline hydrates $\mathrm{CoCl}_{2} \cdot \mathrm{nH}_{2} \mathrm{O}(\mathrm{n}=1,2,4,5,6)$ are famous for their ability to change their color depending on the amount of crystallization water (blue-violet monohydrate, violet dihydrate, dark red tetrahydrate, red pentahydrate, pink hexahydrate).

However, we cannot find literature where the possibility of application such sensors to determine small values of $\mathrm{W}$ of transformer oils would be described. This paper demonstrates the effective application of $\mathrm{CoCl}_{2}$ for the determina- 
tion of $\mathrm{W}$ of transformer oils by optical spectrophotometry in the visible and UV spectral region.

\section{METHODS}

\section{Samples}

One of the most commonly used in the power industry of the Russian Federation, GK grade transformer oil is produced mainly from West Siberian oils, produced using hydrocracking and Catholic dewaxing processes. Five samples of mineral GK grade transformer oil (JSC Angarsk Petrochemical Company, class IIA, TC 38.101.1025-85), used in power transformers and switches, with different values of $W$ in the range from 2 to $50 \mathrm{ppm}$ were selected for this study, as well as anhydrous $\mathrm{CoCl}_{2}$ obtained by the dehydration of $\mathrm{CoCl}_{2} \cdot 6 \mathrm{H}_{2} \mathrm{O}$ crystalline hydrate (purissimum).

Ultraviolet-visible absorption spectra were recorded at room temperature by a Varian Cary 100 spectrophotometer. Model Cary 100 allows you to work with a reference sample in real time and has the ability to program the width of the optical slit. During the measurements, we use cuvettes has a thickness of $10 \mathrm{~mm}$, the wavelength range of $200-800 \mathrm{~nm}$, a speed of 600 $\mathrm{nm} / \mathrm{min}$, a slit width of $1.5 \mathrm{~nm}$. The position of the bands in the spectra is given with an accuracy of $2.5 \mathrm{~nm}$.

\section{RESULTS AND DISCUSSION}

An absorption spectrum of transformer oil (curve 1) with an empty reference cuvette is described in detail in our previous works. In figure 1, the absorption bands at 450 and $420 \mathrm{~nm}$ refer to naphthacene compounds, and at $380 \mathrm{~nm}$ to anthracene ones. An abrupt change in optical density (D) near $400 \mathrm{~nm}$ arises due to the absorption and dispersion of radiation by colloidal and solid particles which are present in transformer oil. Adding $\mathrm{CoCl}_{2}$ powder to transformer oil leads to an increase in $\mathrm{D}$ in the range of 360-490 nm (curve 2), while an increase in $\mathrm{W}$ of the sample leads to an increase in the intensity of this absorption band (curve 3 ).

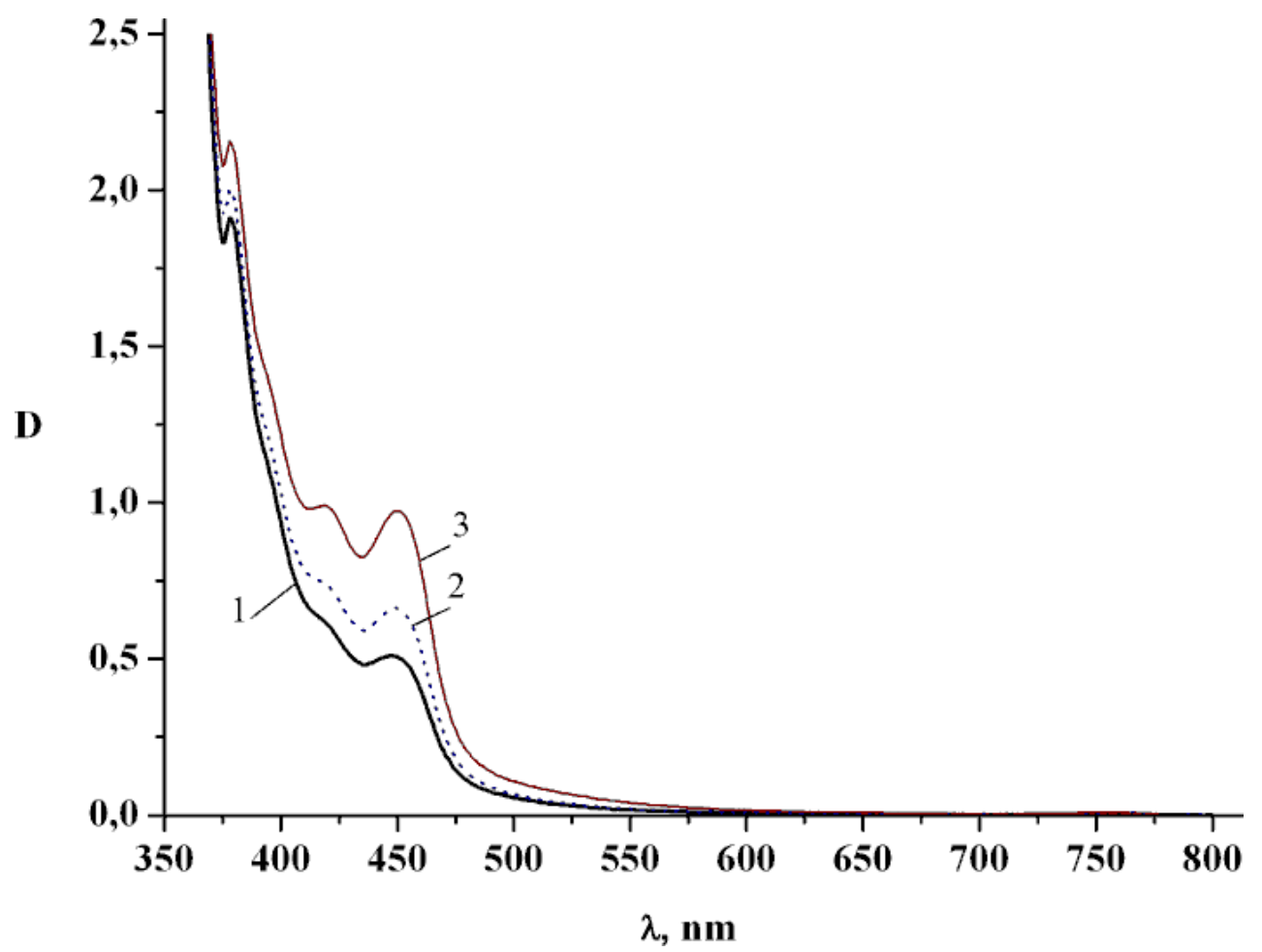

Figure 1. UV/Vis absorption spectra of transformer oil (1), transformer oil with the addition of $\mathrm{CoCl} 2$ (2) and with the subsequent addition of water to the same sample (3). The reference cuvette was empty.

The most probably, an increase in the intensity of the absorption band is caused by the formation of $\mathrm{CoCl}_{2}$ crystalline hydrates with water which is present in transformer oil. The absorption band of $\mathrm{CoCl}_{2} \cdot \mathrm{nH}_{2} \mathrm{O}$ is in the range of 
400-550 nm [29] and crosses the considered range of $360-490 \mathrm{~nm}$.

For greater clarity, the reference cuvette was filled with transformer oil with $\mathrm{W}=10 \mathrm{ppm}$ and with adding the $\mathrm{CoCl}_{2}$ powder in it and then the difference UV/Vis absorption spectra were recorded for several transformer oil samples with different $\mathrm{W}$ and also added $\mathrm{CoCl}_{2}$.
For transformer oil samples with $\mathrm{W}<10 \mathrm{ppm}$ the values of $\Delta \mathrm{D}_{450}$ (i.e. $\Delta \mathrm{D}$ at $\lambda=450 \mathrm{~nm}$ ) are negative, and consequently, such samples of transformer oil are suitable for further use. Otherwise, if $\mathrm{W}>10 \mathrm{ppm}$, the values of $\Delta \mathrm{D}_{450}$ are positive that indicates the unsuitability of such transformer oils for further use.

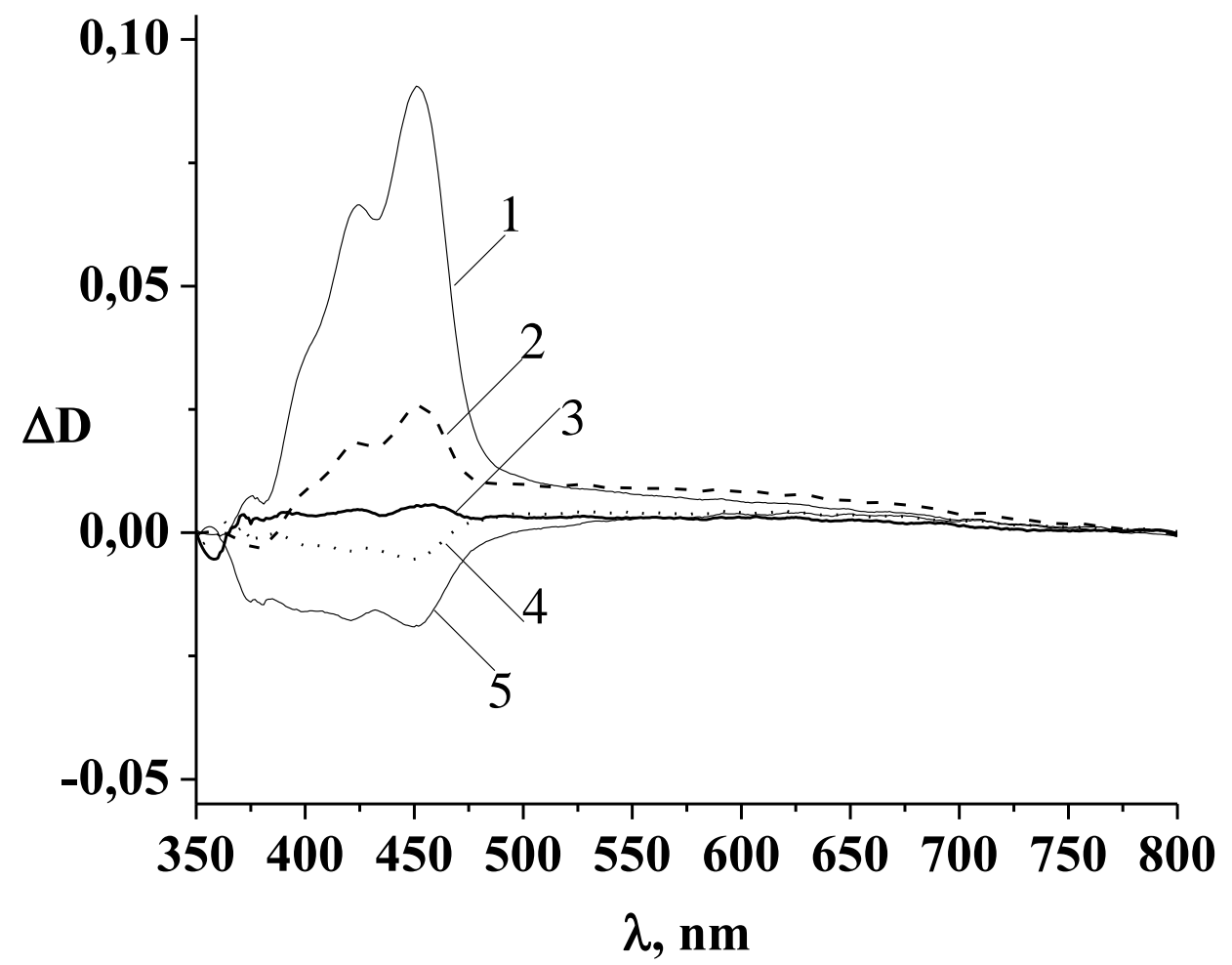

Figure 2. The difference UV/Vis absorption spectra of transformer oil with the addition of $\mathrm{CoCl}_{2}$. The reference cuvette is filled with transformer oil having $W=10 \mathrm{ppm}$. If the studied transformer oil has $W>$ $10 \mathrm{ppm}$, then $\Delta \mathrm{D}_{450}>0$ (lines 1-3), otherwise $\Delta \mathrm{D}_{450}<0$ (lines 4-5).

\section{Conclusion}

The authors reviewed the most commonly used methods for determining moisture content in power engineering. Also noted are the innovative methods used in the territory of the Russian Federation and the world. The absorption spectra in the ultraviolet and visible regions of five samples of mineral transformer oil of the GK brand, used in power electrical equipment, with the addition of cobalt chloride, were recorded and analyzed. Based on the obtained spectra, conclusions were drawn about the relationship between the optical density of the spectrum in the range of 360-490 $\mathrm{nm}$ and the moisture content of transformer oil when cobalt chloride powder is added. The scientific novelty of the work lies in a fundamentally new optical method for determining small values of moisture content of transformer oils, based on the dependence of the optical properties of cobalt (II) chloride on moisture.

This method has a very high sensitivity and is very promising for solving problems of power industry, because UV/visible spectrophotometers, such as the one used in this work, are quite affordable even for small energy companies. The technical result is a reduction in the time for determining the moisture content in insulating liquids, a decrease in the cost of conducting a sample study, due to the absence of 
expensive reagents and an increase in the accuracy of determining the water content, even if available in small quantities, as well as an improvement in the quality of diagnostics and operability of transformer oil and the efficiency of control.

The proposed method application is promising for solving problems of electric power industry in the field of determining the permissible moisture content in insulating oils, since UV and Vis spectrophotometers are accessible and easy to operate, which greatly simplifies the practical inculcation of the method.

\section{References}

[1] Ivanov K.I. Promegutochnii produkti ipromegutochii reakcii avtookisleniya yglevodorodov edited by Chernogukova I.I. [Intermediate products and intermediate reactions of autooxidation of hydrocarbons] Moscow, Gostekhizdat, 1949, 192 p.

[2] Vanin B.V., L'vov U.N., L'vov M.U., Neklepaev B.N. Pokazateli sostoyaniya izolyacii dlya ocenki vopniknoveniya vnutrenih korotkih zamikanii $\mathrm{v}$ silovih transformatorah [Insulation condition indicators for assessing the occurrence of internal short circuits in power transformers] Moscow, Electric stations, 2003, no. 2, pp. 65-69.

[3] Lipshtein R.A., Shakhnovich M.I. Transformer oil. 2d ed., rev. and enl. Jerusalem, Israel, 1970, 257 p. (Russ. ed.: . Lipshtein, R. A.; Shakhnovich, M. I. Transformatornoe maslo. Moscow, 1983, 296 p.)

[4] Wilson A.C.M., Insulating liquids: their uses, manufacture and properties, London, 1980, 221 p.

[5] Margolis S.A., Mele T. Systematic bias in the measurement of water in oils by tubular oven evaporation and azeotropic distillation. Anal. Chem., 2001, vol. 73, no. 20, pp. 4787-4792.

[6] Margolis, S. A. Amperometric Measurement of Moisture in Transformer Oil Using Karl Fischer Reagents. Anal. Chem., 1995, vol. 67, no. 23, pp. 4239-4246.

[7] Margolis S.A. Source of the difference between the measurement of water in hydrocarbons as determined by the volumetric and coulometric Karl Fischer methods. Anal. Chem., 1999, vol. 71. No. 9, pp. 1728-1732.

[8] Gilbert R., Jalbert J., Tetreault P. Bias Assessment of Current Technologies Used for the Determination of Low Levels of Moisture in Mineral Oil Samples. Anal. Chem, 2001, vol. 73, no. 3, pp. 520-526.

[9] Margolis S.A. Effect of Hydrocarbon Composition on the Measurement of Water in Oils by Coulometric and Volumetric Karl Fischer
Methods. Anal. Chem., 1998, vol. 70. no. 20, pp. $4264-4270$.

[10] Margolis S.A. Sources of Systematic Bias in the Measurement of Water by the Coulometric and Volumetric Karl Fischer Methods, Anal. Chem., 1997, vol. 69, no. 23, pp. 4864-4871.

[11]GOST 7822-1975. Masla I smazki. Metod opredeleniya rastvorennoi vodi. [State Standard 7822-1975 Oils and greases. Dissolved water determination method] Moscow, Standartinform Publ.,, 2002. 10p.

[12] Arakelian, V.G., Fofana, I. Water in oil filled high voltage equipment, Part II: Water content as physicochemical tools for insulation condition diagnosis. IEEE Electr. Insul. Mag. 2007, vol. 23, pp. 15-24.

[13] Yusoff S.F.A.Z., Mezher M.H., Amiri I.S., Ayyanar N., Vigneswaran D., Ahmad H., Zakaria R., Detection of moisture content in transformer oil using platinum coated on D-shaped optical fiber, Optical Fiber Technology, 2018, vol. 45, 2018, pp. 115-121.

[14]N'cho JS, Fofana I. Review of Fiber Optic Diagnostic Techniques for Power Transformers. Energies. 2020; vol. 13, no. 7, pp.1789 doi: 10.3390/en13071789

[15]CIGRE, Working Group D1.52. Moisture Measurement and Assessment in Transformer Insulation-Evaluation of Chemical Methods and Moisture Capacitive Sensors; CIGRE Report 741; CIGRE: Paris, France, 2018.

[16] Rodriguez-Rodriguez J.H., Martinez-Pinon F, Alvarez-Chavez J.A, Jaramillo-Vigueras D. [Polymer optical fiber moisture sensor based on evanescent-wave scattering to measure humidity in oil-paper insulation in electrical apparatus]. In Proceedings of the IEEE SENSORS, Lecce, Italy, 2008.

[17] Laskar S., Bordoloi S. Monitoring of moisture in transformer oil using optical fiber as sensor. $J$. Photonics, 2013, pp. 528478.

[18]Zhang W., Webb D.J. PMMA based optical fiber bragg grating for measuring moisture in transformer oil. IEEE Photonics Technol. Lett., 2016, vol. 28, pp. 2427-2430.

[19] Kung P., Idsinga R., Durand H.-C.V., Lu H., Kahriz M. [Fiber optics sensor monitoring moisture transport in oil in an operating transformer]. In Proceedings of the IEEE Electrical Insulation Conference (EIC), Baltimore, MD, USA, 2017, pp.487-490.

[20]RD 34.43.107-95. Metodicheskie ykazaniaya po opredeleniyu soderganiya vodi I vozduha $v$ transformatornom masle. [Procedural Guidelines for the Determination of Content of Water and Air in Transformer Oil] Moscow, AO VNIIE, 1996, 41p.

[21] Carev N.I., Carev V.I. Katarkov I.B. Prakticheskaya gazovaya hromotografiya [Practical gas 
chromatography] Barnaul, Altai State University Publishing House, 2000, 156 p.

[22] Hmelnickii R.A., Brodskii E.S. Metodi analiticheskoi himii. Hromato-mass-spectroskopiya. [Analytical chemistry methods. Chromato-mass spectroscopy.] Moscow, Chemistry Publishing House, 1984, 216 p.

[23] Anikeeva M.A. Opyt provedeniya sravnitel'nyh ispetanii transformatornogo masla na priborah Transport $X i$ himicheskoi laboratorii [Experience in comparative tests of transformer oil on Transport $\mathrm{X}$ and chemical laboratory instruments] Available at: http://www.electropergam.ru/info.html?id=11 (in russian). (accessed 19.04.2020)

[24] Water Detection System WDS 400. Available at: http://vladisart.ru/products/languages/watersearch.html. (accessed 23.12.2019)

[25] Gunter H. NMR Spectroscopy: Basic Principles, Concepts and Applications in Chemistry, 3rd Edition, Berlin, Wiley-VCH, 2013, 734p.

\section{Information about authors.}

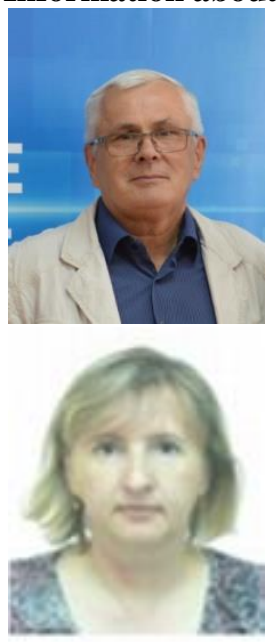

Kozlov

Konstantinovich,

Ph.D., Professor. Research

interests: diagnostics of

the technical condition of

oil-filled electrical

equipment

Email: kozlov_vk@bk

Turanova Olga

Alekseevna, Ph.D., senior researcher. Research interests: diagnostics of oil-filled equipment of power systems, study of physicochemical

properties of organic compounds, optical and magnetic resonance spectroscopy of complex systems

Email: lightur@mail.ru
[26] Konstantaki M., Pissadakis S., Pispas S., Madamopoulos N., Vainos N.A. Optical fiber long-period grating humidity sensor with poly(ethylene oxide)/cobalt chloride coating. Applied Optics, 2006, vol. 45, Issue 19, pp. 45674571.

[27] Yeo T.L., Sun T., Grattan K.T.V. Fibre-optic sensor technologies for humidity and moisture measurement. Sensors and Actuators A, 2008, vol. 144, pp. 280-295.

[28] Russell A.P., Fletcher K.S. Optical sensor for the determination of moisture. Anal. Chimica Acta, 1985, vol. 170, pp. 209-216.

[29] Otsuki S., Adachi K. Humidity dependence of visible absorption spectrum of gelatin films containing cobalt chloride. J. App. Polymer Science, 1993, vol. 48, Issue 9, pp. 1557-1564.
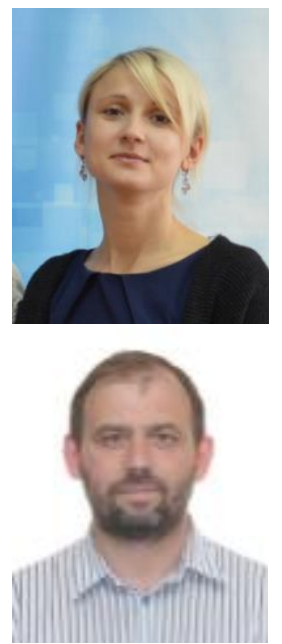